\title{
The Theosophy of Sheikh Mutamakkin's Rebellion (A Study On Yadispura's Serat Cebolek (1729-1983)
}

\author{
Muhajir ${ }^{1}$, Cecep Jaenudin ${ }^{2}, \mathrm{Ani}^{3}$ \\ UIN Sunan Kalijaga Yogyakarta ${ }^{1}$ \\ UIN Sunan Kalijaga Yogyakarta ${ }^{2}$ \\ IAIN Pekalongan ${ }^{3}$ \\ \{azkakunaufa@gmail.com ${ }^{1}$, cecepjogja@gmail.com², ani.2019@student.uny.ac.id ${ }^{3}$ \}
}

\begin{abstract}
The 18th century AD or the era of Mataram Kartosuro witnessed the history of the "controversy" of Sheikh Mutamakkin's thoughts (herein after referred to as SM) in the Text of the Serat Cebolek. The SM controversy was caused by several things. First, he had the courage to reject the policies of the authorities regarding the "prohibition" of teaching Sufism to the common society. Second, SM theosophical teachings were considered to be deviating from the mainstream theosophy, such as the Naqshbandiyah, and it, therefore, is classified as the inkar al-sunnah group. Third, SM decided to become an "opposition" againts the authorities. His opposition attitude was actually born from the social-political context of Mataram Kartosuro which he considered it againts the noble values of Islam. Unfortunately, SM is portrayed in Serat Cebolek as a "rebel" actor who seems to only play the role of an antagonist and heretic. This article argued that SM served indeed as a roleplayer who is able to break the deadlock over the relationship between the creatures and their creator, and between the people and their rulers. The concept of the SM's theosophy has been able to provide the foundation of Sufism which is down to earth and shows the authorities the meaning of life. For him, religious teachings should not be interpreted as a politics-power, rather as a politicsstrategy, a politics-culture, and a politics-humanity. Serat Cebolek seemed to discredit Sheikh Mutamakkin as a heretic and anti-ruler. In fact, the text illustrates the cultural strategy of Sheikh Mutamakkin in introducing divine values both to the authorities and to the people.
\end{abstract}

Keywords: Theosophy, Rebellion, Mataram

\section{Introduction}

One of the Javanese literary works that explain the story of Sheikh Mutamakkin is Serat Cebolek [1]. The book with an exposure model in the form of the pupuh-pupuh was written by Raden Ngabehi Yasadipura I ( 1729-1803 ) [2]. Some researchers still disagree about who actually 
wrote Serat Cebolek. Ricklefs is one historian who has a doubt on its attribution to Yasadipura I. However, he noticed that the Javanese people, especially in the palace environment, accepted that Serat Cebolek was the work of R. Ng. Yasadipura [3]. This literature work is quite phenomenal because it contains the story of Sheikh Mutamakkin with his theosophy rebellion.

Sheikh Mutamakkin, as described in Serat Cebolek, is a mystic (Sufi) without personality. Furthermore, he is a figure who has a shallow knowlegde and low in authority and ethics [1]. Some researchers stated that it was a form of discrediting Sheikh Mutamakkin. This brings us to the question why the description of the Serat Cebolek is claimed to be discrediting.

\begin{tabular}{ll}
\hline Text of Cebolek & Mean \\
\hline Ngendika malih sang Prabu & Bersabdalah lagi sang prabu \\
Ya si Kaji Mutamakin & Ya tentang si Haji Mutamakkin itu \\
Patute wonge kaya pa & Orangnya seperti apa \\
Rahaden Demang Wotsari & Raden Demang Wotsari (bilang) \\
Kadi Cantrik wisangkatha & Seperti Cantrik wisangkatha \\
Anrenggiling api pati & (Yang dapat bersikap) seperti trenggiling api mati \\
& (bersikap seperti bunglon) \\
\hline
\end{tabular}

In the sociohistorical context, there are at least two things that confirm the reason why the description of Sheikh Mutamakkin is considered a form of discretion. The first Serat Cebolek was written by R. Ng. Yasadipura I as a poet of the Keraton Surakarta. It is interesting to note that the text is not the only one that tells the story of Sheikh Mutamakkin. There are still other texts which contain the story of this one Sufi cleric, one of which is the Kajen Text. This last reference is a collection of oral histories among Sheikh Mutamakkin's communities. Some of the stories continues to live now among the people whose parents have the experience of an immediate living with Sheikh Mutamakkin. The reason is that the Kajen area, which is situated in Pati Regency, has become one of the centers of Sheikh Mutamakkin's religious activities during his lifetime. The presence of the Kajen Text becomes a comparison for Serat Cebolek in recalling the stories of Sheikh Mutamakkin. It turned out that the Kajen Text has a far different description from the Serat Cebolek [4]

Second, the position of religious understanding in the palace environment is sharia oriented. This can be seen in several points of heresy and shallow knowledge that was attributed to Sheikh Mutamakkin. For example, the story about dogs that are kept and named with Abdul Qahar and Qamaruddin by the Sheikh. In the literatures of Islamic jurisprudence, this animal is considered impure because of which some people tend to avoid the animal and its pejoration (Dhaib: 32-33). However, in Sufism dogs are deemed as fellow creatures of Allah Swt. from which people can learn how to practice religion (Attar, 2018: 128), as what Sheikh Mutamakkin did. Another argument is that the palace clerics noticed that Sheikh Mutamakkin is fond of watching and listening to wayang with the story of the Bima Suci (Werkudoro) and Dewa Ruci. The scripturalists, who are mostly sharia-oriented, will be naturally allergic to these cultural texts. However, the tasawuf clerics like Sheikh Mutamakkin are able to construct a purse-story of Bima Suci and Dewa Ruci as a spiritual journey towards the human figure 'Insan Kamil' [5]. 


\begin{tabular}{ll}
\hline Text of Cebolek & Meaning \\
\hline Angger asune satunggal & Ananda anjingnya yang satu \\
Winastan pun Kamarodin & Dinamakannya Komarudin \\
Satunggilipun Dulkahar & Setelah yang satunya lagi Abdul Kahar \\
Gumer kang sami miyarsi & Tertawa terbahak-bahak yang mendengarnya \\
Demang Ngurawan nenggih & Sedangkan Demang Ngurawan \\
Ngentrog wentis sami ngguguk & Menghentak-hentakan betis sambil tertawa \\
Ketib Anom sru mojar & Khatib Anom berkata dengan lantang \\
Rika uga mboten becik & Kau juga tidak baik \\
Mindhik-mindhik agawe guyon negara & Menunduk-nunduk sembunyi menjadi tertawaan negara
\end{tabular}

All these indicated that historically the scholars who gave birth to the Serat Cebolek were dominated by those sharia- oriented scholars. As a result, they relied on power to freely discredit Sheikh Mutamakkin and bring various violent discourse against the Sufi clerics.

Serat Cebolek was born at the center of the palace's power at that time. Of course, this sociopolitic historical context can not be separated from the interests of the power holders. Taking Azyumardi Azra's opinion that political history is almost about the history of the rulers and elites, the type of history in the text narrows and even tends to marginalize the "small people", including groups or movements that are seen as against the mainstream. Azra calls this groups as people without history [6]. Ketib Anom Kudus is one of the government officials who stood up as a symbol of the ruler and the mainstream, while Sheikh Mutamakkin represented a group of "small people" whose history are kept being dark and obliterated. From this explanation, it is understandable why Serat Cebolek discredited the understanding and the movement of Sheikh Mutamakkin's rebellion.

The end of the story of Sheikh Mutamakkin in Serat Cebolek was not as tragic as the fate of Sheikh Siti Jenar in the court table of the Wali Songo assembly [7]. The defeat of Sheikh Mutamakkin's debate from Ketib Anom Kudus made him charged with the death sentence by burning alive. However, Sunan Amangkurat IV did not answer the petition of the clerics until the end of his life, while his successor Pakubuwono II, after investigating the case, forgave but ordered Sheikh Mutamakkin to keep away from making actions that will disrupt the stability of the palace through his teachings on sufism.

\begin{tabular}{llll}
\hline Text of Cebolek & Meaning & & \\
Sun sirep parentah Ingsun & Aku batalkan perintahku & & \\
Aja na kang ngrasani & Jangan ada yang mempersoalkan & & \\
Kang luput wus sun apura & Yang bersalah telah kuampuni & \\
Kaki Ahmad Mutamakkin & Kaki (sebutan untuk orang laki-laki) Ahmad \\
& Mutamakkin & \\
\hline
\end{tabular}

In his Muqadimah, Ibn Khaldun said that kingdoms and dynasties could only be upheld with the help and solidarity of the people [8]. The steps of Sunan Amangkurat IV and Pakubuwono II 
who postponed and cancelled the execution of Sheikh Mutamakkin in Serat Cebolek have a relevance with what Ibn Khaldun said above. Pakubuwono II found that since the debates of the two ulamas had contributed to the distability of public security, this would be an anomaly in the efforts of the palace officials campaigning for the Sufi-King concept in order to strengthen the power legitimacy. The influence and pressure from the outside began to spread in and out of the palace and the Sheikh Mutamakkin's theosophical movement became more massive and wide. In another theory, Ibn Khaldun also said that all acts of excessive violence would be very dangerous for the sovereignty of a state and could even lead to [8].

The conflict in the poems of the Serat Cebolek between Sheikh Mutamakkin and Ketib Anom Kudus resulted in a ruling structure of a panatagama (a religious leader) and its supports from the ulama and priyayi. Therefore, Serat Cebolek is not a book on Sufism, rather on ideology campaign used by the authorities [9]

\section{Method}

This research is a historical studi using a socio-historical approach equipped with a discourse on sufism. The socio-historical approach is used to examine the social aspects following the story of Sheikh Mutamakkin, in addition to his pure historical knowledge. On the other hand, a discourse sufism is meant to reveal the thoughts of Sheikh Mutamakkin on sufism.

\section{Result and Discussion}

Context is a condition in which an event occurs. In a simple way, context is a situation that accompanies the emergence of a text, whereas the contextual context is related to a particular context. Noeng Muhadjir said that there are at least three different meanings in contextual words. The first is various efforts to understand the meanings in anticipating the current problems. The second is that something will be seen from its historical points of the past, the present, and the functional significance and the predictions in the future. The third is the connection between the center and periphery [10].

\section{Rejecting The Sufism Exclusiveness}

Harun Nasution said that Sufism aims to approach God as intensive as possible so one can see Him with the mind and even soul being united with the Spirit of God (Rakhmat, 2008: 59). There is no single group that is justified as the most legitimate in Sufism. Every servant of God has the same access in Sufism. The essence of Sufism, Harun sais, is to get closer to God. Therefore, the path of Sufism is an inclusive road, not an exclusive space.

Azyumardi Azra inferred from the thoughts of Sheikh Yusuf al-Maqassari that Sufism is only for the elite [6]. The reason is that in the nomenclature of God's servants, as conceptualized by alMaqassari, there are classes of ahl-khawwash and khashsh al-khawwash. There is no doubt that not all practitioners of Sufism can reach the peak of the highest maqam. Every turn from one maqam to another maqam is inseparable from God's help. 
However, when giving an introduction to the book Urban Sufism compiled by Martin van Bruinessen and Julia Day Howell, Azra realized that the current era post modernity and globalization showed symptoms of a revival of Sufism. The teachings of spirituality like Sufism find its momentum not only among the middle class, but also among the grassroots [11]. Similarly, Harun Nasution found also that the world's today is suffered to the epidemic of materialism. This disease attacks the spiritual and social immune system as to cause largely complicated social problems. There are a lot of people saying that to deal with the plague means to reactivate the teachings of spirituality. At the end, Harun underlined that the revival of spirituality is identical with spiritual purification and good characters without neglecting the profane dimensions of life (Rakhmat, 2008: 84-85).

Sheikh Mutamakkin called for the similar thing in his efforts being labelled as a rebel. Ever religious servant attempts to climb up the closest maqam to his God. Sufism is not the property of the elite or a certain circle. The grassroots are also entitled to obtain the same spiritual enlightenment. Sufism in his hand should not be made exclusive, rather it should be an inclusive and down to earth spirituality.

\section{Sufism is Not an Instrument of Political Legitimacy}

The struggle of Sheikh Mutamakkin in Serat Cebolek gave a rise to another face of Sufism which lies outside the walls of the palace. Different colors made collisions between the two. The authorities want to make Sufism as a tool of legitimation power through the concept of sufi-kings in which various supernatural attributes are attached to make it stronger. The vision of mukasyafah in Sufism is kept away from the communities who are obliged to follow what delivered by the palace only. This is compounded by the bureaucrat clerics around the palace who actually took Sufism or mysticism as a means of power legitimacy [4].

Used as an instrument of power legitimacy, Sufisim will bring with it cultural oppression. This context will lead to what Marx predicted that religion is one of the tools for the authorities to oppress [12]. Karl Marx said that people are taught to be patient in facing various situations, hoping for rewards and heaven. In the case of Sheikh Mutamakkin, the concept of the king-Sufi will give the ruler a total submission from the people from whom the king can have everthing he wish.

Amin Syukur said that Sufism at this time should no longer stand outside the power [13]. Rather, it has now to embody its responsibilities into a political arena or even entering into "power". The reason is that power now is not at the hands of one person but of a collegial decision. It should be underlined here that religious doctrine or Sufism still does not become an instrument of legitimacy of power. However, the agenda of Sufism has been now expanding. The agenda carried by Sufism at the political level is not about power politics. Rather, Sufism serves as a strategic, cultural, and humanitarian politics. 


\section{Egalitarianism before God}

The teachings of Muhammad Khakiki or the nature of Muhammadiyah suggested that every human being has the same radiance of Nur Muhammad's since birth. The ultimate understanding of Nur Muhammad's presence is that there is a pure dimension as a servant of God (nasut) and a divine dimension (lahut) in every human body. When the process of selfpurification continues, the lahut dimension will dominate in which God becomes easily present, filling the inner cavities in human beings. The great Sufi al-Hallaj calls this condition Hulul, which means the presence of God is captured by the human's lahut dimension (Rakhmat, 2008: 78-80).

Ibn Arabi, the Sufi who taught Nature of Muhammadiyah, explained that human beings are different and diverse. Nevertheless, they are mentally the same thanks to the light of al-Haqq [13]. Therefore, there is the same prototype in all humans in their status as the pests of God where discrimination is no longer justified. The teachings of Sufism at the political level brings with itu an egalitarian mission of all servants of God, regardless of being the ruler or the ruled, the majority or the minority.

Antonio Gramsci sees that religion, as a cultural resource, can be a useful means for the reformers or the elites who are supporting the status quo. In this sense, Sufism initiated by Sheikh Mutamakkin is considered a revolutionary Sufism seeking to undermine the hegemony of the Sufi kings in the palace. This led to a clash between Sheikh Mutamakkin and Ketib Anom Kudus. In Serat Cebolek, the Sheikh is described as the defeated. However, the presence of the Kajen Text has challenged Serat Cebolek for discrediting figures and hegemony of knowledge. The birth of the Serat Cebolek within the palace walls strengthened the thesis that its existence is meant to become an instrument for the power legitimacy and to shadow the cultural resistance by Sheikh Mutamakkin.

In addition, the teaching of Muhammad Khakiki or the Nature of Muhammadiyah that Sheikh Mutamakkin brougt to the political level conveys the concept of an egalitarian servant before God, criticizing various practices of discrimination carried out by the power holders. What Mutamakkin did in his labelled revolutionary rebellion was basically driven by his love for God, his monotheistic paradigm, and his love for egalitarian humanity. This accords what Che Guevara stated that a true revolutionary is guided by a strong sense of love and it is impossible to imagine the steps of a revolutionary without those feelings (Prasetyo, 2012: 53). This is why Sheikh Mutamakkin did not refuse, escape, or even resist when Susuhunan Pakubuwono II was calling him.

\section{Conclusion}

We can draw some conclusions from the explanation. First, Serat Cebolek written by R. Ng. Yasadipura explained the conflict between Sheikh Mutamakkin and the Mataram Kertosuro coastal clerics led by Ketib Anom Kudus. Susuhunan Pakubuwono II successfully reconciled them. Second, Sheikh al-Mutamakkin was a figure of Sufism, a cultural cleric who played a significant role in spreading the message of Islam in the north coast (pantura) of Java in the 18th century AD. The regions where he did the da'wah stretched from Tuban, Rembang to Kajen in Margoyoso, Pati. Third, Mutamakkin's theosophy includes the teachings on harmonization of the Shari'a, Muhammad Khakiki (The Nature of Muhammadiyah), and divine freedom (al- 
hurriyah). Sheikh Mutamakkin was delivering his teaching through local cultural texts, such as the story of Bimasuci and Dewaruci. The three teachings above are claimed to be heretical by the majority of the coastal scholars who were in fact the bearers of the royal authority. Sheikh Mutamakkin was also labeled as a rebel because of his teachings opposing the vision of the kingSufi palace. Fourth, contextualization of Mutamakkin's theosophical teachings will lead to an egalitarian social life. Sufism, in the political context, is not a means of power legitimacy, rather a source of energy to light up political strategy, culture, and political humanity. Sufism does not only belong to the elite, everyone has the rights and space to access mukasyafah with a circumstance that us getting them to be closer with God.

\section{Reference}

[1] Z. B. Milal, Syekh Mutamakkin: Perlawanan Kultural Agama Rakyat. Tanggerang: Pustaka Compass, 2014.

[2] H. Nasuhi, "Yasadipura I (1729-1803) Biografi dan Karya-Karyanya," Bul. Al-Turas, vol. 12, no. 3, pp. 211-222, 2006.

[3] M. . Ricklefs, “The Yasadipura Problem,” BKI, vol. 153, no. 2, p. 276, 1997.

[4] M. S. W. Bagus and Sariyatun, "Pemikiran Neo-Sufisme Sheikh Ahmad Mutamakkkin," Theologia, vol. 29, no. 2, p. 38, 2018.

[5] A. Rif'an, "Kearifan Lokal (Local Wisdom) Syekh Ahmad Al-Mutamakkin (1645-1740 M]) dan Pemikiran Pendidikan Pesantren," J. Stud. Sos., vol. 5, no. 2, p. 89, 2013.

[6] A. Azra, Historiogtafi Islam Kontemporer: Wacana, Aktualitas dan Aktor Sejarah. Jakarta: Gramedia, 2002.

[7] A. Sidqi, "Mendaras Manunggaling Kawula Gusti Sheikh Siti Jenar," Din. Penelit., vol. 17, no. 1, p. 8, 2017.

[8] I. Khaldun, Muqadimah, 14th ed. Jakarta: Pustaka Firdaus, 2017.

[9] P. F. dan J. A. K. F. Irfan, "Serat Cebolek. Sufism Book or Ideology Documents or Javanese Priyayi?," el-Harakah, vol. 20, no. 1, 2018.

[10] M. Solahudin, "Pendekatan Tekstual dan Kontekstual dalam Penafsiran al-Qur'an," alBayan, vol. 1, no. 2, 2016.

[11] M. Van Bruinessen and J. D. Howell, Urban Sufism. Jakarta: Rajawali Press, 2008.

[12] M. U. Babul, Genealogi Hadits Politis al-Mu'awiyat dalam Kajian Islam Ilmiah. Bandung: Marja, 2018.

[13] A. Syukur, Menggugat Tasawuf: Sufisme dan Tanggungjawab Sosial Abad 21. Yogyakarta: Pustaka Pelajar, 2012. 